\title{
Determining the radiation use efficiency of potato using sunshine hour data: a simple and costless approach
}

\author{
Suman Samanta (Samanta, S) ${ }^{1,2}$, Saon Banerjee (Banerjee, S) ${ }^{2}$, Asis Mukherjee (Mukherjee, A)², Pulak K. Patra (Patra, PK) \\ and Pramiti K. Chakraborty (Chakraborty, PK) ${ }^{3}$ \\ ${ }^{I}$ Visva-Bharati, Dept. of Environmental Studies, Santiniketan, West Bengal 731235, India ${ }^{2}$ AICRP on Agrometeorology, BCKV, Kalyani, Nadia, West \\ Bengal 741235, India ${ }^{3}$ BCKV, Dept. Agr. Meteor. Phys., Mohanpur, Nadia, West Bengal 741252, India
}

\begin{abstract}
Aim of study: Radiation parameters and photoperiod influence potato biomass and tuber yield significantly. Lack of instrument facilities in developing countries is the main hindrance to estimate global solar radiation (GSR) and radiation use efficiency (RUE). Considering these facts, an experiment was conducted to estimate light extinction coefficient $(K)$ and RUE using a simple but indirect approach that can be implied in any location lacking sophisticated instruments.

Area of study: Field experiments were conducted in Kalyani, West Bengal, representing the Indo-Gangetic Plains.

Material and methods: Angstrom-Prescott (A-P) equation was used to calculate GSR. The experiment was laid out in a split-plot design with three dates of planting (DOP), $15^{\text {th }}$ Nov, $29^{\text {th }}$ Nov and $13^{\text {th }}$ Dec, as main plot treatment and three potato cultivars ('Kufri Surya', 'Kufri Chandramukhi' and 'Kufri Jyoti') as sub-plot treatment. Leaf area indices and $K$ values were used to determine intercepted PAR (IPAR) as well as RUE.

Main results: The cumulative IPAR from emergence to harvest ranged 246-429 $\mathrm{MJ} \mathrm{m}^{-2}$ depending on planting time and varieties. Irrespective of DOPs, the highest mean RUE (4.19 $\left.\mathrm{g} \mathrm{MJ}^{-1}\right)$ was calculated in 'Kufri Chandramukhi', showing that it used the radiation more efficiently that the other two cultivars ('Kufri Surya' $=3.75 \mathrm{~g} \mathrm{MJ}^{-1}$ and 'Kufri Jyoti' $=3.14 \mathrm{~g} \mathrm{MJ}^{-1}$ ).

Research highlights: Statistical indices confirmed that the A-P model can be reliably used in the study region for estimation of GSR. This simple way to estimating RUE using bright sunshine hours data can be used in developing countries, where costly radiation instruments are not available.

Additional keywords: solar radiation; photosynthetically active radiation; light extinction coefficient; leaf area index

Abbreviations used: A-P (Angstrom-Prescott); BSS (bright sunshine hour); DAP (days after planting); DOP (days of planting); GSR (global solar radiation); IGP (Indo-Gangetic plains); IPAR (intercepted PAR); K (light extinction coefficient); KC (Kufri Chandramukhi); KJ (Kufri Jyoti); KS (Kufri Surya); LAI (leaf area index); MAPE (mean absolute percentage error); MBE (mean bias error); MPE (mean percentage error); NSE (Nash Sutcliffe efficiency); PAR (photosynthetically active radiation); RI (radiation interception); RMSE (root mean square error); RUE (radiation use efficiency); SR (solar radiation); TPAR (transmitted PAR)

Authors' contributions: Conception and design of the study: SS. Data collection and analysis: SS and PKC. Language check: SB and AM. Statistical analysis: PKP. All authors contributed in manuscript writing and interpretation of results.

Citation: Samanta, S; Banerjee, S; Mukherjee, A; Patra, PK; Chakraborty, PK (2020). Determining the radiation use efficiency of potato grown in Eastern India from sunshine hour data: a simple approach. Spanish Journal of Agricultural Research, Volume 18, Issue 2, e0801. https://doi.org/10.5424/sjar/2020182-15561

Received: 02 Aug 2019. Accepted: 27 Apr 2020

Copyright (c) 2020 INIA. This is an open access article distributed under the terms of the Creative Commons Attribution 4.0 International (CC-by 4.0) License.

Competing interests: The authors have declared that no competing interests exist.

Correspondence should be addressed to Saon Banerjee: sbaner2000@yahoo.com
\end{abstract}

\section{Introduction}

Potato (Solanum tuberosum L.) is one of the most important vegetable crops in terms of quantities produced and human consumption (Devaux et al., 2014; FAO, 2017). Bowen (2003) reported that production of potato is exceeded only by wheat, rice and maize when the global food consumption is considered. The crop grows better in cold temperature except in frostfree seasons (Hijmans, 2003; Haverkort \& Verhagen,
2008). At global level, India ranks third (after China and Russia) in potato acreage covering a land of 2.02 million hectares and stands second (only after China) in tuber production, producing 46.4 million tons per annum (FAO, 2014). More than $85 \%$ of potato area is confined to Indo-Gangetic Plains (IGP), where it is grown from post monsoon season until winter (November to February) with irrigation facilities and contributes more than $80 \%$ to the total tuber production of the country (Pandey \& Kang, 2003). Climatic variables 
like solar radiation (SR), temperature and rainfall determine the distribution of potato in India. In Europe, Temmerman et al. (2002) studied the effect of latitude, seasonal mean air temperature (ranging from 13.8 to 19.9 ${ }^{\circ} \mathrm{C}$ ), SR (ranging from 12.0 to $21.3 \mathrm{MJ} \mathrm{m}^{-2} \mathrm{~d}^{-1}$ ), humidity, soil moisture and atmospheric $\mathrm{CO}_{2}$ concentrations on tuber production. Levy \& Veilleux (2007) reported that high temperature affects the sprout development, tuber initiation, partitioning of assimilates and yield while frosts affect the crop growth and eventually it even shorten the duration of crop.

Among the main environmental factors that strongly govern all physiological processes of the plants, the global solar radiation (GSR) flux density, air temperature and available soil water content should be considered primarily (Coelho \& Dale, 1980). Stuttle et al. (1996) observed that tuber yield improvements might be obtained by increasing the net daily photosynthetically active radiation (PAR) through higher solar irradiance or longer photoperiod. The visible portion $(0.4$ to $0.7 \mu \mathrm{m}$ wavelength) of the solar spectrum is extremely important as it serves as the sole energy source for photosynthesis (McCree, 1972; Myers, 2005; Tsubo $\&$ Walker, 2005). Photoperiods control the tuber production by maintaining the balance between gibberellic acid and abscisic acid secretion in plant (Dwelle, 1985). Van der Zaag \& Doornbos (1987) also found that dry matter accumulation of crops including potato grown under non-limiting conditions is directly related to the amount of intercepted radiation. Cumulative seasonal PAR was calculated as the product of incident PAR and PAR interception on a daily basis summed up to harvest. Thus, growth rate of agricultural crops can be linearly related to intercepted PAR (IPAR) when soil water is adequate (Gallagher \& Biscoe, 1978). Due to the non-availability of PAR measurement facilities, this parameter is often calculated indirectly based on its relationship with SR. Analyzing the spectral distribution of incoming SR at sea level, Moon (1940) observed that when sun was more than 300 above horizon, then $44 \%$ to $45 \%$ of incoming SR is PAR. Incident PAR was assumed as $45 \%$ of the total incoming SR by Meek et al. (1984). Monteith (1973) suggested that the PAR can be taken as half of the total SR in the tropics as well in temperate latitude. But according to many researchers, PAR percentage is not always constant, but vary according to location, season, sky clearness, sky brightness and atmospheric depth for the solar beam, relative bright sunshine hour (BSS) duration and water vapour pressure, altitude, day length, etc. (Baigorria et al., 2004; Finch et al., 2004; Jacovides et al., 2004; Tsubo \& Walker, 2005; Wang et al., 2007; Li et al., 2010). Thus it is clear from the above findings that the relationship between PAR and SR needs to be calibrated according to the local climatic conditions.
GSR is becoming increasingly appreciated because it is either the primary or secondary source of energy for each and every living organism. But in developing countries including India, there are very few meteorological stations which measure GSR. India Meteorological Department can supply the radiation data of only one station for whole West Bengal, although its area is 88,750 $\mathrm{km}^{2}$. Hence, the researchers of this zone have to rely on different indirect approaches estimation of GSR from other meteorological parameters. Some researchers used the sunshine duration (Salima \& Chavula, 2012; Umoh et al., 2014), others used the relative humidity and temperature (Fagbenle \& Karayiannis, 1994), while a few used the number of rainy days, sunshine hours and a factor that depends on latitude and altitude (Skeiker, 2006; Chiemeka, 2008). According to several research works, SR data calculated from sunshine duration achieve the highest degree of precision for agricultural and hydrological studies (Akpabio \& Etuk, 2003; Trnka et al., 2005; Sahin, 2007; Li et al., 2011). The first ever empirical model to estimate GSR, based on the relationship between daily global irradiation and BSS, was proposed by Angstrom in the year 1924 (Angstrom, 1924).

Leaf is the principal photosynthetic functional unit because the area and arrangement of foliage or canopy architecture, determine the interception of SR by a crop and the distribution of irradiance among individual leaves (Favarin et al., 2002; Loomis \& Connor, 2002; Tavares Jr et al., 2002; Dammer et al., 2008). The efficiency of interception of PAR depends on the leaf area of the plant population as well as on the shape and inclination angle of the leaf or canopy (Kiniry et al., 2004). Watson (1947) defined leaf area index (LAI) as a dimensionless variable and the total one-sided area of photosynthetic tissue per unit area. According to Boken \& Chandra (2012), a high value of LAI represents a denser or healthier crop canopy; while a low value indicates sparse or dry canopy. The light extinction coefficient $(K)$ describes the capacity of the canopy of light interception. It is mainly crop specific but can differ a little on the basis of cultivated varieties and on the orientation of the leaves, and the planting pattern and the values may vary from 0.3 to 1.5 (Zarea et al., 2005). Kiniry et al. (2001) delineated the fact that lower values of $\mathrm{K}$ allow a better light penetration into the canopy and along with high LAI results in a better RUE. As already discussed, under no stressed conditions (i.e., with adequate water and nutrient supply), cumulative dry matter is linearly related to the amount of SR or PAR intercepted by the crop canopy and the slope of this regression is known as RUE (Monteith, 1972, 1977; Purcel et al., 2002; Soltani et al., 2006). It has been observed that different species have their own growth rate depending on their specific RUE (Condori 
et al., 2008). Manrique et al. (1991) observed higher potato yield at higher altitude which may be due to lower night temperature and lower photorespiration at higher elevation. As a consequence higher RUE values were observed with increase of altitude. Nevertheless, according to Kiniry et al. (1990) and Demetriades-Shah et al. (1992), large variation in RUE values is not solely dependent on radiation interception but also on soil and other climatic factors.

The objectives of the present investigation were to: i) validate the Angstrom equation for calculation of GSR for the study region; ii) estimate the extinction coefficient for three popular potato cultivars; and iii) evaluate PAR use efficiency of potato grown in Gangetic West Bengal.

\section{Material and methods}

\section{Study site}

The present study was carried out during three consecutive winter seasons (2012 to 2014) at the 'C' Block Farm of Bidhan Chandra Krishi Viswavidyalaya, Kalyani $\left(22^{\circ} 59^{\prime} 13^{\prime \prime} \mathrm{N}, 88^{\circ} 27^{\prime} 20^{\prime \prime}\right.$ E, altitude $\left.10.8 \mathrm{~m}\right)$, West Bengal, India. The study area belongs to the IGP of Eastern India and is characterized by tropical sub-humid climate with hot and humid summer seasons. During monsoon seasons, the south-west monsoon circulation system accommodates necessary energy and water vapour from the Bay of Bengal and carries the moist air to the inland of the continent which provides around $73 \%$ of the total annual rainfall $(1443.5 \mathrm{~mm})$ of the region (Samanta et al., 2012). However, winter season receives $40.5 \mathrm{~mm}$ rainfall which is only $2.83 \%$ of mean total annual rainfall. They also reported that in recent past, onset of monsoon (normal date is 8th June for the region) has been delayed by one week to 10 days. Long term (1960-2015) data analysis shows that May is the hottest month of the year $\left(36.0{ }^{\circ} \mathrm{C}\right.$ average). January is the coolest month throughout the year as the mean monthly temperature remains close to 11.0 ${ }^{\circ} \mathrm{C}$. During winter months, the mean monthly maximum temperature ranges from 25.5 to $29.1{ }^{\circ} \mathrm{C}$ and the mean monthly minimum temperature ranges from 11.0 to 15.0 ${ }^{\circ} \mathrm{C}$. The mean monthly average BSS always ranges between 7.1 and $8.1 \mathrm{hr} \mathrm{d}^{-1}$. During winter, fog is observed only at early morning hours. The soil of the study area is mainly alluvial in nature (Entisol) and silty clay in texture. The percentage of the silt, clay and sand are 72.2, 21.7 and $6.1 \%$ respectively. The soil is slightly basic (7.45) in nature and also well-drained.

\section{Field experiments and cultivation management}

Field experiment was laid out in a split-plot design to assess the performances of potato cultivars under actual weather condition with irrigation supply i.e., with no water stress to constantly monitor their canopy structure and light interception. In lower Gangetic West Bengal, the potato planting window generally starts from post monsoon period i.e., mid-November and continues up to December. Following local farmers' practice, potato cultivars were planted on three days starting in $15^{\text {th }}$ Nov with 14 days interval $\left(D_{1}=15^{\text {th }}\right.$ Nov; $D_{2}=29^{\text {th }}$ Nov; $D_{3}=13^{\text {th }}$ Dec $)$. The net plot size was $22.5 \mathrm{~m}^{2}(5 \mathrm{~m} \times 4.5 \mathrm{~m})$ with three replications and pre-sprouted seed tubers were planted at a spacing of $50 \mathrm{~cm}$ (row to row) $\times 15 \mathrm{~cm}$ (plant to plant). Main plots and sub-plots were divided by a $1.25 \mathrm{~m}$ irrigation channel and $0.75 \mathrm{~m}$ bund respectively acting as a buffer.

We selected three Indian potato varieties, 'Kufri Surya' (KS), 'Kufri Chandramukhi' (KC) and 'Kufri Jyoti' $(\mathrm{KJ}) . \mathrm{KC}$ is known to be heat-susceptible and the other two heat-tolerant varieties (Minhas et al., 2006). In the first year, we started our experiment with two varieties (KS and $\mathrm{KJ}$ ) and the third one, $\mathrm{KC}$, was included in the second year. The recommended dose of fertilizer $(\mathrm{N}: \mathrm{P}: \mathrm{K}=200: 150: 150)$ was applied through urea $(46 \% \mathrm{~N})$, single superphosphate $\left(16 \% \mathrm{P}_{2} \mathrm{O}_{5}\right)$ and muriate of potash $\left(60 \% \mathrm{~K}_{2} \mathrm{O}\right)$. The full dose of $\mathrm{P}$ and $\mathrm{K}$ were applied as basal dose, but urea was applied in three splits. Half of the urea was applied during soil preparation and the rest was equally divided and applied as top dressing during earthing up [at 20 days after planting (DAP)] and during second irrigation (at 30 DAP). Every year, data collection was started at 30 DAP and continued up to maturity with 15 days interval. During sampling, proper care was taken to avoid edge effect

\section{Meteorological observation and weather data collection}

Daily maximum and minimum temperature, sunshine hour, relative humidity, rainfall, wind speed, rainy day, pan evaporation and cloud cover were recorded for the study period at Kalyani Meteorological Observatory, situated at AICRP on Agrometeorology, Bidhan Chandra Krishi Viswavidyalaya. The GSR values $\left(\mathrm{W} \mathrm{m}^{-2} \mathrm{sec}^{-1}\right)$ with a wavelength of $0.3-3.0 \mu \mathrm{m}$ on a horizontal surface were recorded from Aug 2013 to Dec 2015 using a Pyranometer sensor (Kipp \& Zones CMP6 model) mounted at $1.5 \mathrm{~m}$ height. During the crop growth period, diurnal variation of incident and transmitted PAR (TPAR) were measured 
at weekly interval starting from 8 am to $4 \mathrm{pm}$ with a gap of one hour. A line quantum sensor (Model No.: Q-301, APOGEE, Logan UT, UK) was used manually to capture the radiation in and above the canopy. To maintain parity with GSR, PAR data were also converted into its energy flux ( $\left.\mathrm{W} \mathrm{m}^{-2} \mathrm{sec}^{-1}\right)$ using the constant conversion factor of 1.08 .

NASA POWER website also provides SR data along with other meteorological parameters for $1^{\circ} \times 1^{\circ}$ (i.e., $\sim 110 \mathrm{~km} \times \sim 110 \mathrm{~km}$ ) resolution across the world. For the study period, the daily global solar irradiance and GSR values were collected from the NASA POWER website (NASA POWER, 2016) and compared with the observed GSR data. The comparison was done to find out the possibility of using the NASA POWER in the study region.

\section{Calculation of GSR from Angstrom equation}

The facility to measure GSR using Pyranometer sensors is scanty in developing countries like India. Hence, GSR is calculated from different empirical equations using temperature, BSS, rainfall, cloud cover etc. Nowadays satellite imageries are also widely used. But among the existing correlations, the following relation is the widely accepted modification of Angstrom-type regression equation, relating the clear sky GSR to BSS duration. Angstrom (1924), one of the pioneers, first proposed the equation, which was later modified by Prescott (1940) and Page (1961) to its present form which is popularly known as Angstrom-Prescott (A-P) correlation and presented as:

$$
\mathrm{H} / \mathrm{H}_{0}=\mathrm{a}+\mathrm{b}(\mathrm{n} / \mathrm{N})
$$

where $\mathrm{H}=$ incoming daily GSR ( $\mathrm{MJ} \mathrm{m}^{-2} \mathrm{~d}^{-1}$ ); $\mathrm{H} 0=$ daily extra-terrestrial radiation $\left(\mathrm{MJ} \mathrm{m}^{-2} \mathrm{~d}^{-1}\right)$; a and $\mathrm{b}=$ empirical constants; $\mathrm{n}=$ bright sunshine hours per day (hr); $\mathrm{N}=$ astronomical day length (hr). $\mathrm{N}$ was calculated by the following formula:

$$
\mathrm{N}=\frac{2}{15} \cos ^{-1}[-\tan (\varnothing) * \tan (\delta)]
$$

where $\Phi=$ latitude in radian; $\delta=$ solar declination angle in radian.

H0 was calculated using the equation defined by Martinez-Lozano et al. (1984):

$$
\begin{gathered}
\mathrm{H}_{0}=37.6[1+0.33 \cos (0.0172 k)][\omega \sin (\phi) \sin (\delta)+ \\
\sin (\omega) \cos (\phi) \cos (\delta)]
\end{gathered}
$$

where $k=$ Julian day and $\omega=$ sunset hour angle in radians; $\delta$ and $\omega$ can be calculated from the following expressions:

$$
\begin{aligned}
\delta & =0.409 \sin (0.0172 k-1.39) \\
\omega & =\operatorname{arc} \cos [-\tan (\phi) \tan (\delta)]
\end{aligned}
$$

\section{Calculation of $\mathrm{K}$ and RUE}

Based on the measured values of LAI and PAR data (incident PAR above the canopy and incident PAR transmitted through the canopy) amount of $K$ of the crop was determined using the Beer-Lambert equation, which is an exponential form of the equation (Sarmadnia \& Koocheki, 1994; Goudriaan \& van Laar, 1994; Whisler et al., 1986; Thornley \& France, 2007):

$$
\mathrm{I}_{\mathrm{t}} / \mathrm{I}_{0}=e^{-K * \mathrm{LAI}}
$$

where $\mathrm{I}_{\mathrm{t}}=$ transmitted PAR (TPAR), $\mathrm{I}_{0}=$ incident PAR and $K=$ light extinction coefficient. From this equation, we can calculate IPAR as:

$$
\operatorname{IPAR}=\mathrm{I}_{0}\left(1-\mathrm{e}^{-K * \text { LAI }}\right)
$$

RUE was calculated from the slope of the linear regression of cumulative IPAR on cumulative dry biomass obtained from the sequential samplings (Kiniry et al., 2001).

In the present study, LAI was measured during each biomass sampling through gravimetric technique. A circular cutter of known diameter $(2.5 \mathrm{~cm})$ was used to cut randomly chosen ten green leaves. After that the cut pieces were dried in a hot air oven. By using the area-weight relationships, leaf area of leaf samples from $1-\mathrm{m}^{2}$ were calculated. Then the LAI was obtained using standard formulas (Watson, 1947; Gardner et al., 1985):

$$
\text { LAI }=\frac{\text { Leaf area }\left(\mathrm{cm}^{2}\right)}{\text { Ground or surface area }\left(\mathrm{cm}^{2}\right)}
$$

\section{Testing the performance of Angstrom equation}

Performance of the Angstrom equation for this region was tested by using some statistical indicators. Besides correlation coefficient (r), and coefficient of determination $\left(\mathrm{R}^{2}\right)$ :

-Mean bias error (MBE) is simply the average of the predicted value minus the average observed value:

$$
\text { MBE }=\frac{1}{N} \sum_{i=1}^{N}\left(P_{i}-O_{i}\right)
$$


where $\mathrm{P}_{\mathrm{i}}$ is the calculated GSR, $\mathrm{O}_{\mathrm{i}}$ is the observed GSR and $\mathrm{N}$ is the number of observations.

-Mean absolute error (MAE) is the average of the absolute difference between predicted and observed value:

$$
\operatorname{MAE}=\frac{1}{\mathrm{~N}} \sum_{\mathrm{i}=1}^{\mathrm{N}}\left(\left|\mathrm{P}_{\mathrm{i}}-\mathrm{O}_{\mathrm{i}}\right|\right)
$$

-Standard error (SE) was calculated comparing the actual value and the model output value. The equation of standard error of the predicted value is:

$$
\mathrm{SE}=\sqrt{\frac{1}{(\mathrm{~N}-2)} \sum\left(\mathrm{O}_{\mathrm{i}}-\overline{\mathrm{O}}_{\mathrm{i}}\right)^{2}-\frac{\left[\sum\left(\mathrm{P}_{\mathrm{i}}-\overline{\mathrm{P}}_{\mathrm{i}}\right)\left(\mathrm{P}_{\mathrm{i}}-\overline{\mathrm{P}}_{\mathrm{i}}\right)\right]^{2}}{\sum\left(\mathrm{O}_{\mathrm{i}}-\overline{\mathrm{O}}_{\mathrm{i}}\right)^{2}}}
$$

-Root mean squared error (RMSE) is simply the root of the MSE value. It is usually better to report the RMSE than the MSE, because the RMSE is measured in the same units as the data, rather than in squared units.

$$
\operatorname{RMSE}=\sqrt{\frac{1}{\mathrm{~N}} \sum_{\mathrm{i}=1}^{\mathrm{N}}\left(\mathrm{P}_{\mathrm{i}}-\mathrm{O}_{\mathrm{i}}\right)^{2}}
$$

-Mean percentage error (MPE) can be defined as the percentage deviation of the monthly average daily radiation values estimated by the model used from the measured values:

$$
\mathrm{MPE}=\frac{1}{\mathrm{~N}} \sum 100 * \frac{\left(\mathrm{O}_{\mathrm{i}}-\mathrm{P}_{\mathrm{i}}\right)}{\mathrm{O}_{\mathrm{i}}}
$$

-Mean absolute percentage error (MAPE):

$$
\mathrm{MAPE}=\frac{1}{\mathrm{~N}} \sum 100 *\left|\frac{\left(\mathrm{O}_{\mathrm{i}}-\mathrm{P}_{\mathrm{i}}\right)}{\mathrm{O}_{\mathrm{i}}}\right|
$$

- Nash Sutcliffe efficiency (NSE):

$$
\mathrm{NSE}=1-\frac{\sum_{\mathrm{i}=1}^{\mathrm{n}}\left(\mathrm{O}_{\mathrm{i}}-\mathrm{P}_{\mathrm{i}}\right)^{2}}{\sum_{\mathrm{i}=1}^{\mathrm{n}}\left(\mathrm{O}_{\mathrm{i}}-\overline{\mathrm{O}}_{\mathrm{i}}\right)^{2}}
$$

These parameters are most commonly used to compare the model output value with the observed value (Tadros, 2000; Sabziparvar \& Shetaee, 2007; Banerjee et al., 2016). All these statistical tests, including ANOVA test for biological parameters, were done using MS-Excel. $\mathrm{R}^{2}$ denotes the multiple coefficient of determination, which is a measure of how well the regression equation fits the sample data whereas RMSE conveys information on the short term performance of different equations since it enables a term-by-term comparison of the actual variations between the estimated and measured value. For more accurate estimation, lower values of RMSE should be obtained (Akpabio \& Etuk, 2003). The values of MBE represent the systematic error or bias. The closer the MBE, RMSE and MPE are to zero, the better the model is. Positive values represent overestimation and negative values represent underestimation. If the value of $\mathrm{R}$ is close to unity, the model is said to be better. MPE is a test of long term performance of the examined regression equation and its positive and negative value represents similar trends like MBE. For a better model performance, a low value of MPE is desirable and the percentage error between $-10 \%$ and $+10 \%$ is considered acceptable (Menges et al., 2006). NSE is a simple measure to determine the model precision by plotting observed values against simulated data in a 1:1 line. Generally, NSE ranges between $-\infty$ and 1.0 and the model is more efficient when NSE is closer to 1 .

\section{Results}

\section{Comparison of measured and estimated GSR}

The daily GSR was measured during the potato growing seasons (2013-14 to 2015-16) and simultaneously the GSR was calculated through Angstrom equation. The value of empirical coefficients $a$ and $b$ of the A-P correlation varied from 0.3143 to 0.4476 . Fig. 1 shows the relationship between the measured and calculated incoming daily GSR $\left(\mathrm{MJ} \mathrm{m}^{-2}\right)$ for the horizontal soil surface during the said period. Testing of accuracy of the Angstrom equation in the study region was done by calculating MBE, RMSE, $\mathrm{R}^{2}, \mathrm{MPE}$, NSE, etc. and has been summarized in Table 1. It has been observed that throughout the crop growing season, the mean monthly GSR received on earth surface was at its lowest magnitude in the month of December (11.8-15.2 $\left.\mathrm{MJ} \mathrm{m}^{-2} \mathrm{~d}^{-1}\right)$ and reached its highest value during February and March (17.9-25.3 $\mathrm{MJ} \mathrm{m}^{-2} \mathrm{~d}^{-1}$ ) resulting a sharp increase in air temperature. Testing of the applicability of NASA POWER in this region revealed that in most of the cases the website underestimated the GSR data.

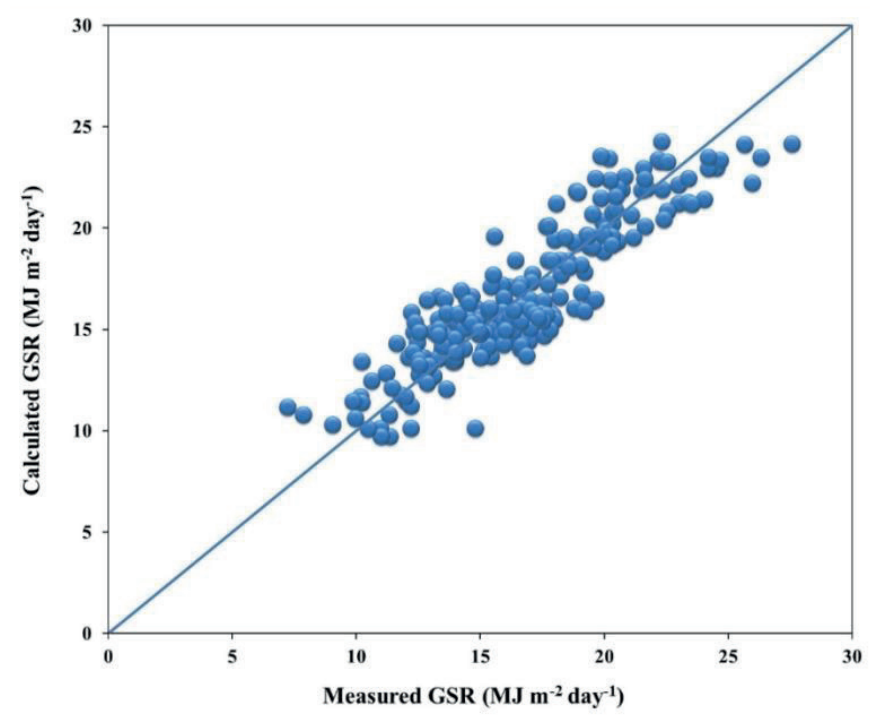

Figure 1. Comparison between measured and calculated daily global solar radiation (GSR) during the post monsoon and winter seasons of the three years studied. 
Table 1. Comparison of the accuracy of calculated and NASA POWER (2016) provided global solar radiation (GSR) with mean monthly measured GSR over the study period. Total sample size $=333$

\begin{tabular}{|c|c|c|c|c|c|c|c|c|c|}
\hline \multirow{2}{*}{ Year } & \multirow{2}{*}{\multicolumn{3}{|c|}{$\begin{array}{c}\text { GSR }^{(1)} \\
\left(M^{-2} \mathbf{~ m}^{-2} d^{-1}\right) \\
\end{array}$}} & \multicolumn{5}{|c|}{ Months } & \multirow{2}{*}{ Mean } \\
\hline & & & & Nov & Dec & Jan & Feb & Mar & \\
\hline \multirow[t]{3}{*}{ 2013-14 } & \multicolumn{3}{|c|}{ Measured } & -- & 15.2 & 15.7 & 18.0 & 17.9 & 16.7 \\
\hline & \multirow{2}{*}{\multicolumn{3}{|c|}{$\begin{array}{l}\text { Calculated } \\
\text { NASA POWER }\end{array}$}} & -- & 14.2 & 14.8 & 19.1 & 18.3 & 16.6 \\
\hline & & & & -- & 13.4 & 15.0 & 18.1 & 18.6 & 16.3 \\
\hline \multirow[t]{3}{*}{$2014-15$} & \multicolumn{3}{|c|}{ Measured } & 16.7 & 16.1 & 14.4 & 20.1 & 25.3 & 18.5 \\
\hline & \multirow{2}{*}{\multicolumn{3}{|c|}{$\begin{array}{l}\text { Calculated } \\
\text { NASA POWER }\end{array}$}} & 16.3 & 14.7 & 13.5 & 18.2 & 22.9 & 17.1 \\
\hline & & & & 15.8 & 14.0 & 13.8 & 17.7 & 21.1 & 16.5 \\
\hline \multirow[t]{5}{*}{$2015-16$} & \multicolumn{3}{|c|}{ Measured } & 16.7 & 11.8 & -- & -- & -- & 14.2 \\
\hline & \multicolumn{3}{|c|}{ Calculated } & 15.8 & 10.9 & -- & -- & -- & 13.4 \\
\hline & \multicolumn{3}{|c|}{ NASA POWER } & 15.6 & 11.3 & -- & -- & -- & 13.4 \\
\hline & \multicolumn{9}{|c|}{ Statistical tests } \\
\hline & $\mathbf{r}$ & $\mathbf{R}^{2}$ & MBE & MAE & SE & RMSE & MPE & MAPE & NSE \\
\hline Calculated & 0.94 & 0.87 & -0.87 & 0.63 & 2.09 & 1.64 & 4.61 & 8.27 & 0.83 \\
\hline NASA POWER & 0.91 & 0.83 & -1.05 & 1.65 & 3.50 & 2.10 & 4.65 & 9.36 & 0.74 \\
\hline
\end{tabular}

${ }^{(1)}$ Mean monthly value. MBE: mean bias error. RMSE: root mean square error. MPE: mean percentage error. MAPE: mean absolute percentage error. NSE: Nash Sutcliffe efficiency.

\section{Relationship between transmitted and intercepted PAR}

The relationship between TPAR and IPAR is fitted best in a polynomial form and represented by a second order polynomial equation. The variation of IPAR and TPAR followed a similar pattern for both $\mathrm{KC}$ and $\mathrm{KJ}$ varieties (Fig. 2). TPAR was higher up to 30 days and the peak of IPAR was noticed around 70 to 75 days for both the cultivars. Irrespective of DOP and variety, PAR interception was around $45 \%$ on 30 days after planting and increased gradually up to $95 \%$ around $75-80$ days. After that, the amount of IPAR decreased gradually due to crop drying.

\section{Derivation of light extinction coefficient $(K)$}

Irrespective of DOP and variety, crops attained its maximum LAI value within 60 to 75 DAP and after that it started to decline resulting a decrease in light interception as well. Slow increase of LAI at an early growing period and rapid increase in middle and decreasing trend at the end up to maturity was observed. Table 2 represents the maximum LAI values of tuber for different years. Maximum LAI (6.0) was achieved by the var. KJ under $\mathrm{D}_{1}$ and $\mathrm{D}_{2}$ closely followed by $29^{\text {th }}$ Nov-planted KC attaining a value of 5.9. Light extinction coefficient was calculated by plotting LAI against the ratio of incident to TPAR through exponential relation and the power of the equation was taken as $K$ value as per Beer-Lambert equation. Values of $K$ for the main crops were similar to values in the literature and generally did not show consistent trends of increasing or decreasing with increasing LAI (Table 2). The value of $K$ was highest for var. KJ under $3^{\text {rd }} \mathrm{DOP}$ and lowest for $\mathrm{KC}$ under $\mathrm{D}_{1}$ (Fig. 3). However, irrespective of DOP, mean $K$ value (0.597) was at highest level under KS closely followed by KC (0.596). The highest $K$ value (0.688) was observed in $\mathrm{KJ}$ under $\mathrm{D}_{3}$ followed by $\mathrm{KC}$ $(0.662)$ cultivated under same DOP. The lowest value of $K$ $(0.488)$ belonged to KC but under $15^{\text {th }}$ Nov-planted crops.

\section{Radiation use efficiency}

By plotting the cumulative biomass against the cumulative IPAR, a linear relationship was observed and the slope of this linear relation is RUE. Table 2 shows that var. $\mathrm{KC}$ had comparatively higher RUE than the other two varieties. The Nov-end-planted crops showed higher RUE than other DOPs. Var. KJ was a poor performer with respect to RUE, although it had highest LAI values throughout its growing period (Fig. 4). $\mathrm{KC}$ variety showed the highest RUE with a mean value of $4.19 \mathrm{~g} \mathrm{MJ}^{-1}$, whereas RUE of KS and KJ varieties was 3.75 and $3.14 \mathrm{~g} \mathrm{MJ}^{-1}$ respectively. There were notable differences in RUE between the two growth stages (vegetative and tuber bulking) as presented in Table 2. Irrespective of variety, RUE values during vegetative and tuber bulking stages ranged 2.25$3.95 \mathrm{~g} \mathrm{MJ}^{-1}$ and 2.77-5.13 $\mathrm{g} \mathrm{MJ}^{-1}$ respectively.

\section{Discussion}

\section{Comparison of measured and estimated GSR}

From the obtained results of empirical coefficients, it can be assessed that they are well within the range derived by previous researchers. For example, Angstrom (1924) 
a)

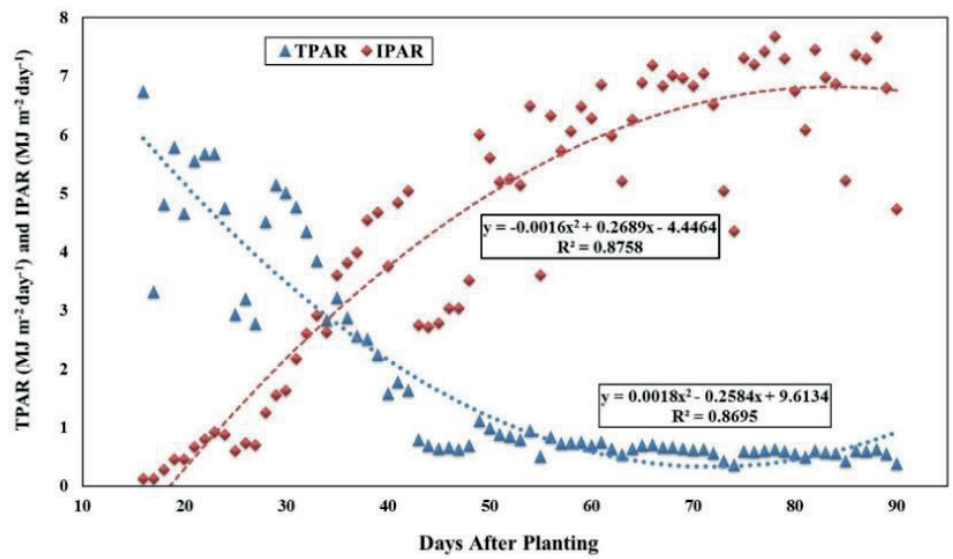

b)

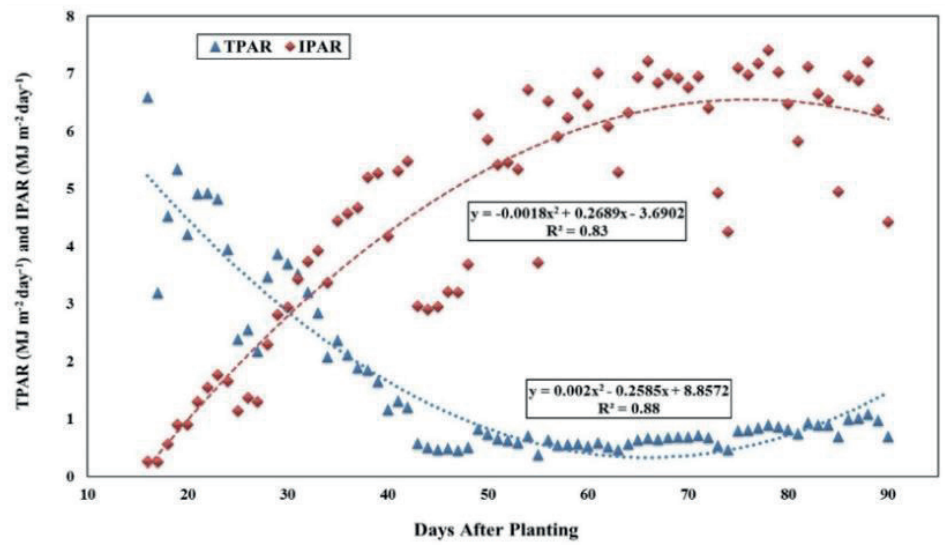

c)

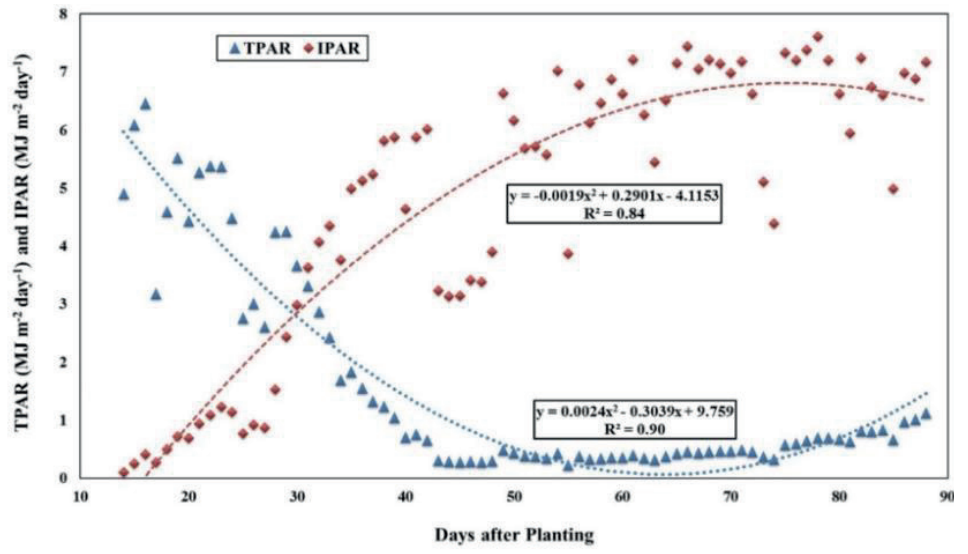

Figure 2. Comparison between incident and transmitted PAR throughout the growing season under D1 treatment (for treatments see Table 2) for (a) var. KS; (b) var. KC; (c) var. KJ

recommended values of 0.25 and 0.75 , respectively for the constants $\mathrm{a}$ and $\mathrm{b}$ based on the data from Stockholm. Martinez-Lozano et al. (1984), after reviewing the literature for 101 locations around the world, reported that the values of $a$ may vary between 0.06 and 0.4 and $b$ between 0.19 and 0.87 . Thus, it is evident that the analysed values of $a$ and $b$ for the present study are also within the range described by different researchers. Irrespective of experimental year and month, Angstrom equation under-estimated GSR very slightly. The low negative MPE value also indicated the underestimation of calculated GSR compared with measured value. The value of MPE was within acceptable range $(-10 \%$ to $+10 \%)$, so the Angstrom equation can be used in the study region for the estimation of GSR. High correlation (88\%) and coefficient of determination $(77 \%)$ values along with low RMSE and SE values indicated that the Angstrom equation can be used safely. NSE values confirm that measured GSR is plotted very well against the estimated data (Fig. 1). Calculation of GSR for different locations across the globe through Angstrom equation provides high accuracy as observed in the present study (El-Sebalii \& Trabea, 2005; Bakirci, 2009; Muzathik et al., 2011; Khorasanizadeh \& Mohammadi, 2013). Acceptable MPE and less RMSE indicated 
Table 2. Phenological stage wise radiation use efficiency (RUE), light extinction coefficient $(K)$ and maximum leaf area index (LAI) value achieved by the three potato varieties under different days of planting (DOP) along with statistical analysis. Total sample size $=27$; number of replications $=3$.

\begin{tabular}{|c|c|c|c|c|c|c|c|}
\hline \multirow{2}{*}{ Treatments } & \multicolumn{3}{|c|}{ Maximum LAI } & \multirow[b]{2}{*}{$K$} & \multicolumn{3}{|c|}{ RUE (g MJ'-1) } \\
\hline & 2012-13 & 2013-14 & 2014-15 & & $\begin{array}{c}\text { Early } \\
\text { vegetative }\end{array}$ & $\begin{array}{c}\text { Tuber } \\
\text { bulking }\end{array}$ & $\begin{array}{l}\text { Whole crop } \\
\text { growth period }\end{array}$ \\
\hline \multicolumn{8}{|l|}{ DOP } \\
\hline $\mathrm{D}_{1}$ & 2.85 & 5.54 & 5.29 & 0.522 & 3.09 & 3.22 & 3.31 \\
\hline $\mathrm{D}_{2}$ & 1.91 & 5.14 & 5.87 & 0.591 & 2.74 & 4.54 & 4.07 \\
\hline $\mathrm{D}_{3}$ & 2.17 & 4.54 & 4.58 & 0.655 & 2.44 & 3.91 & 3.70 \\
\hline SEM & 0.03 & 0.04 & 0.10 & 0.01 & 0.15 & 0.25 & 0.11 \\
\hline $\mathrm{CD}$ & $0.11 * *$ & $0.16^{* *}$ & $0.40 *$ & $0.03 * *$ & NS & NS & NS \\
\hline \multicolumn{8}{|l|}{ Variety } \\
\hline $\mathrm{V}_{1}$ & 2.45 & 5.60 & 5.07 & 0.597 & 2.59 & 3.75 & 3.75 \\
\hline $\mathrm{V}_{2}$ & 2.10 & 4.51 & 5.13 & 0.596 & 2.93 & 4.52 & 4.19 \\
\hline $\mathrm{V}_{3}$ & 2.38 & 5.12 & 5.54 & 0.575 & 2.75 & 3.40 & 3.14 \\
\hline SEM & 0.03 & 0.07 & 0.07 & 0.00 & 0.21 & 0.30 & 0.08 \\
\hline $\mathrm{CD}$ & $0.10^{* *}$ & $0.22 *$ & NS & NS & NS & NS & $0.24 *$ \\
\hline \multicolumn{8}{|l|}{ DOP * Variety } \\
\hline $\mathrm{D}_{1} \mathrm{~V}_{1}$ & 2.79 & 5.61 & 4.61 & 0.564 & 2.70 & 3.43 & 3.36 \\
\hline $\mathrm{D}_{1} \mathrm{~V}_{2}$ & 2.37 & 4.95 & 5.32 & 0.488 & 3.95 & 3.46 & 3.76 \\
\hline $\mathrm{D}_{1} \mathrm{~V}_{3}$ & 3.39 & 6.05 & 5.94 & 0.514 & 2.62 & 2.77 & 2.80 \\
\hline $\mathrm{D}_{2} \mathrm{~V}_{1}$ & 2.13 & 5.81 & 5.67 & 0.613 & 2.82 & 4.04 & 4.24 \\
\hline $\mathrm{D}_{2} \mathrm{~V}_{2}$ & 1.76 & 4.21 & 5.92 & 0.637 & 2.28 & 5.13 & 4.46 \\
\hline $\mathrm{D}_{2} \mathrm{~V}_{3}$ & 1.85 & 5.40 & 6.01 & 0.524 & 3.12 & 4.45 & 3.51 \\
\hline $\mathrm{D}_{3} \mathrm{~V}_{1}$ & 2.44 & 5.36 & 4.93 & 0.615 & 2.25 & 3.77 & 3.65 \\
\hline $\mathrm{D}_{3} \mathrm{~V}_{2}$ & 2.18 & 4.35 & 4.15 & 0.662 & 2.56 & 4.97 & 4.35 \\
\hline $\mathrm{D}_{3} \mathrm{~V}_{3}$ & 1.90 & 3.91 & 4.67 & 0.688 & 2.52 & 2.99 & 3.09 \\
\hline SEM & 0.05 & 0.12 & 0.13 & 0.01 & 0.36 & 0.52 & 0.14 \\
\hline $\mathrm{CD}$ & $0.17 * *$ & $0.38 * *$ & $0.40 *$ & $0.03^{* *}$ & NS & NS & NS \\
\hline
\end{tabular}

$K$ : light extinction coefficient. *Significant at $5 \%$ level, **Significant at $1 \%$ level

that performance of Angstrom equation is viable for both short and long term. Values of MBE, MPE and NSE revealed that A-P correlation fits better compared to NASA POWER (Table 1). The reason may be due to the error occurred during the process of downscaling of SR data.

\section{Relationship between transmitted and intercepted PAR}

The change of values of TPAR and IPAR were well fitted with crop age through second order polynomial equation. The equations for the three varieties were observed significant at $1 \%$ level and confirmed that the pattern of PAR components change over time. Irrespective of variety, the pattern of IPAR and TPAR variation over time followed similar pattern. The intercepted portion increased with growth of crop and increase of LAI. On the other hand, the transmitted portion decreased with growing period due to increase in crop canopy structure. The phenomena can be explained as at the initial stage of crop growth, when the LAI was low, most of the incident PAR was transmitted through crop canopy. Up to 33 DAP, the TPAR was higher than IPAR. With crop growth the IPAR value gradually increased with time up to 80 DAP for var. KS (Fig. 2). Afterwards, due to gradual drying of leaves, the IPAR decreased slowly, but never became lower than TPAR value as observed during initial phase. For the other two varieties, IPAR gradually increased up to 70 days. Irrespective of the dates of planting (DOP) and of the variety, cumulative IPAR from emergence to harvest ranged 246-429 $\mathrm{MJ} \mathrm{m}^{-2}$. In Philippines, Demagante et al. (1996) reported 740, 900 and $945 \mathrm{MJ} \mathrm{m}^{-2}$ radiation interception (RI) for early, medium and late maturing po- 
a)

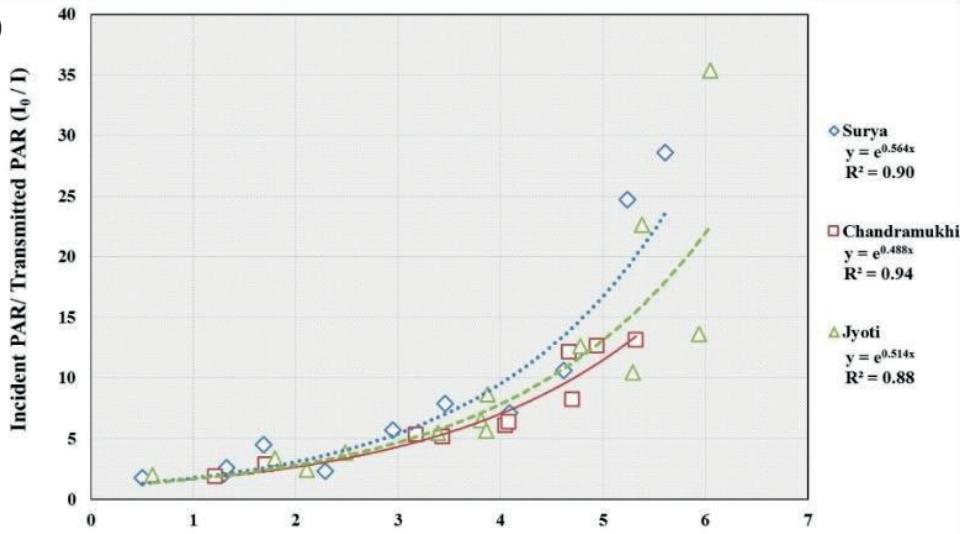

b)
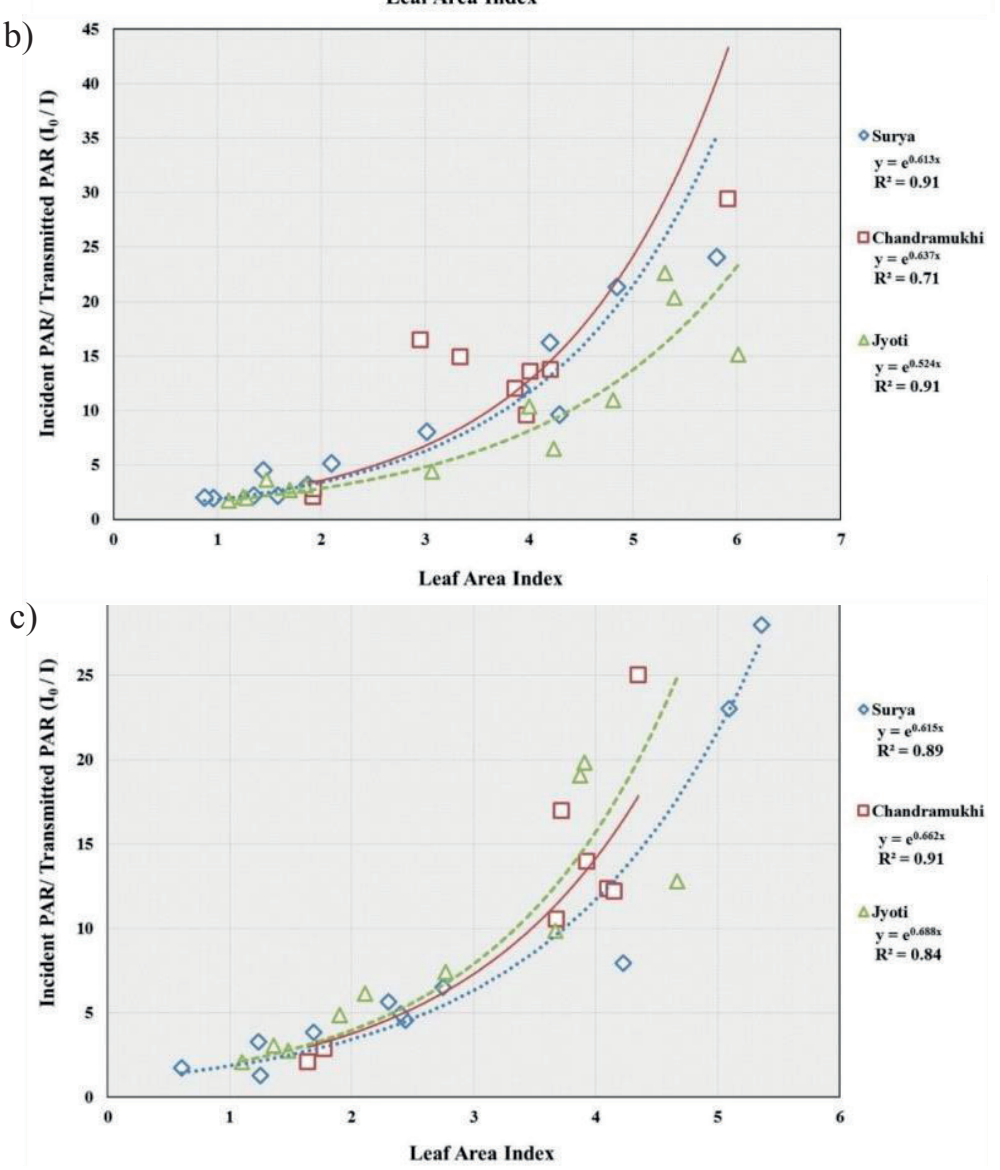

Figure 3. Estimation of light extinction coefficient of the three potato varieties under (a) $D_{1}=15^{\text {th }}$ Nov; (b) $D_{2}=29^{\text {th }}$ Nov; (c) $D_{3}=13^{\text {th }}$ Dec

tato cultivars respectively. Whereas, in Netherlands, RI varied from 1180 to $1435 \mathrm{MJ} \mathrm{m}^{-2}$ for different varieties in different seasons (Haverkort et al., 1991).

\section{Derivation of light extinction coefficient $(K)$}

It was observed that LAI values sharply increased after 30 days. It might be due to the application of urea prior to that time. The decreasing trend after 75 days might be due to senescence of older leaves or leaf damage and leaf drop. Thus it is expected that these differences in LAI values throughout the growing period would lead to wide variations in the amount of radiation intercepted and consequently would be reflected in the accrued total dry weight. Beadle (1993) documented that maximum LAI varied between 6 to 8 for deciduous forest and 2 to 4 for annual crops. But, in general, values of LAI have been reported to vary between 3.5 and 6.0 depending on the cultivar (Wright \& Stark, 1990; Battilani \& Mannini, 1993). Praharaj et al. (2007) observed highest LAI value (4.8) under var. 'Kufri Pukhraj' followed by 'Kufri Ashoka' (2.82). Thus the LAI values measured throughout the growing period of potato were relatively close to the 
a)

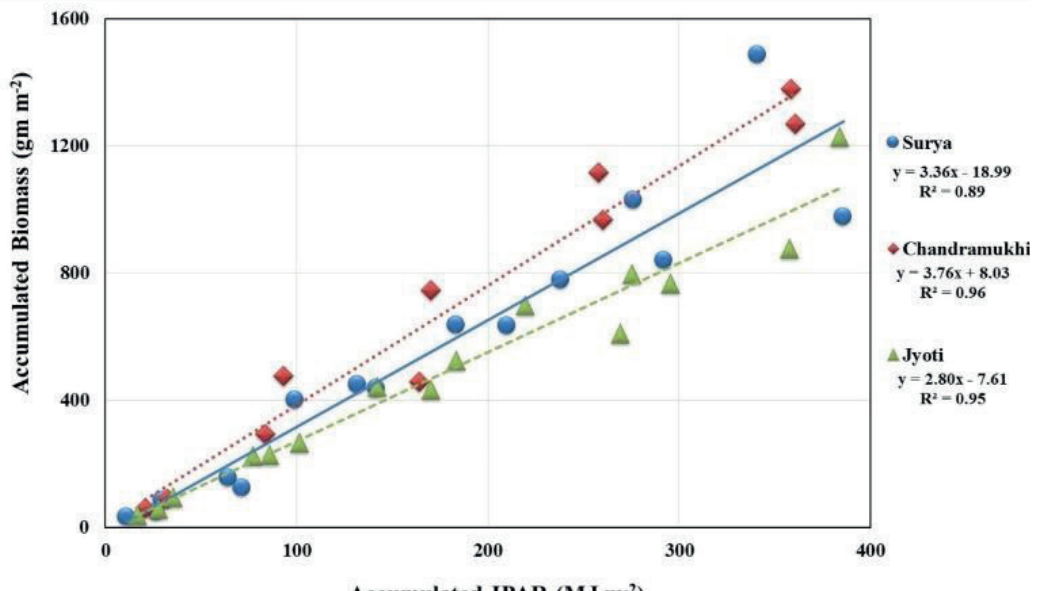

b)

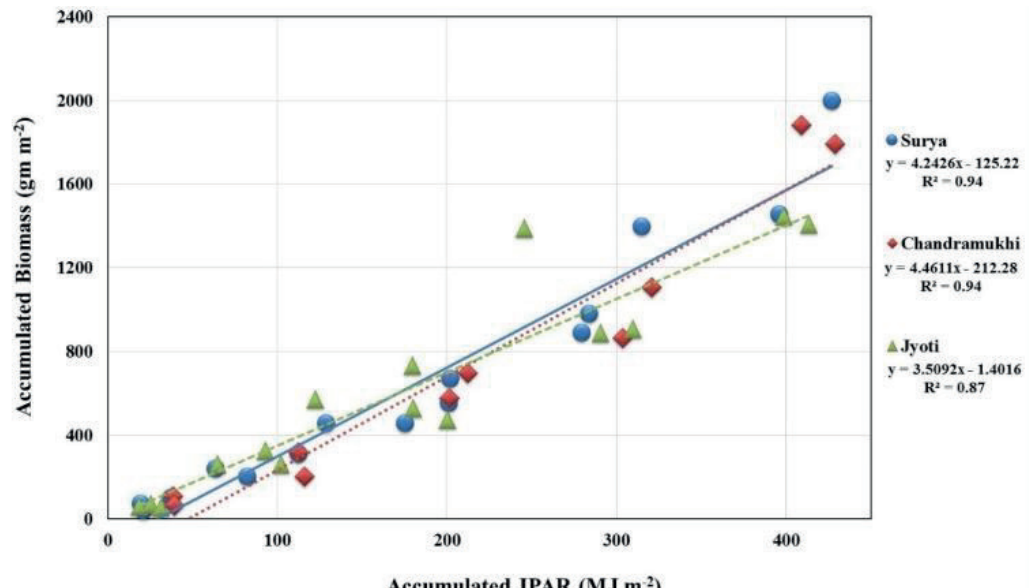

c)

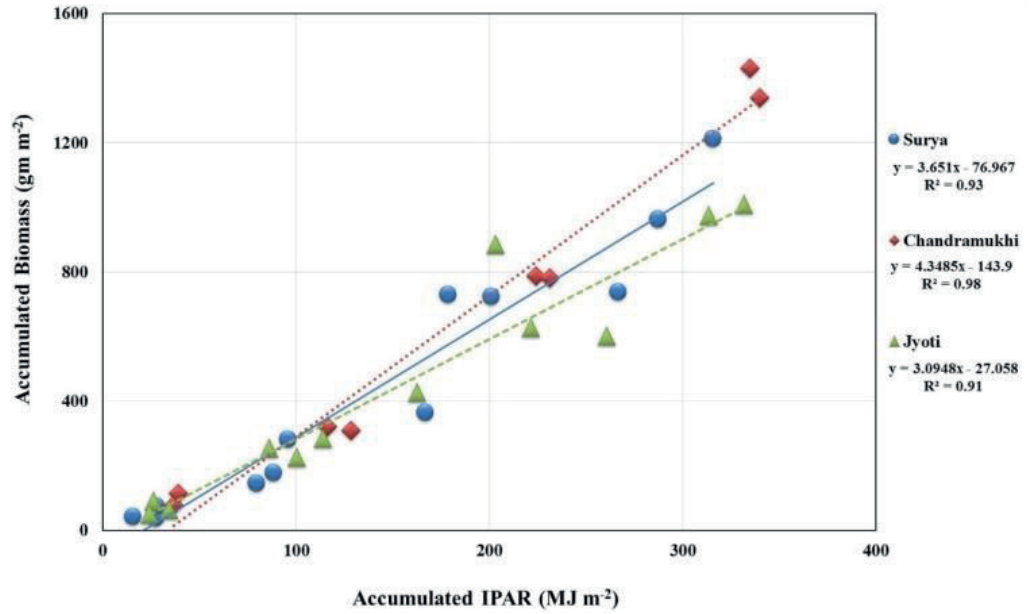

Figure 4. Regression analysis between accrued biomass values and relative cumulated IPAR of three potato cultivars under (a) $D_{1}=15^{\text {th }}$ Nov; (b) $D_{2}=29^{\text {th }}$ Nov; (c) $\mathrm{D}_{3}=13^{\text {th }}$ Dec.

reported values in the literature. The difference in $K$ value of all three cultivars was probably due to differences in canopy morphology. Vijaya Kumar et al. (1993) worked out the $K$ values for non-horizontal orientation of leaves $(<1.0)$ and for horizontal leaves $(>1.0)$. In case of var. $\mathrm{KC}$, more upright leaves were observed and $K$ value was the lowest among the three varieties.

\section{Radiation use efficiency (RUE)}

From Table 2 it can be explained that the $\mathrm{KC}$ variety used the PAR most efficiently than the other two cultivars. Production of dry matter depends on the ability of the crop canopy through the conversion of intercepted radiation energy into biomass and can be presented as RUE. 
Thus RUE may be regarded as indicator of crop performance. Jefferies \& MacKerron (1989) and Nishibe et al. (1989) measured the RUE of potato and also concluded that RUE is the most vital indicator of potato growth and yield. Their measured RUE values were slightly lower than those found in this work, especially during tuber bulking stage. Allen \& Scott (1980) observed RUE values in the range of 3.5 to $3.7 \mathrm{~g} \mathrm{MJ}^{-1}$. The magnitude of RUE is at par with the present study, especially for $\mathrm{KS}$ and $\mathrm{KJ}$ varieties. However, Khurana \& McLaren (1982) reported a range which is lower than our findings.

From data analysis, it seems that vars. $\mathrm{KC}$ and $\mathrm{KJ}$ belong to different domains in terms of RUE which depends on the varietal characteristics. RUE values were at the lowest level during early vegetative stage compare to tuber bulking stage, where the radiation energy converted into photoassimilates by the process of photosynthesis and stored in tuber resulted in greater RUE. High magnitude and intensity of GSR and higher prevailing temperature at the later half of the tuber bulking stage may hamper the crop biomass production and yield due to early drying of the crop. Crops, whose early vegetative stage is completed in December, used the SR efficiently to produce large amount of biomass. The photoperiod of the varieties used in the present study (around $11.0 \mathrm{hrs} \mathrm{d}^{-1}$ ) was well matched with day-length of the study region causing minimum negative impact due to photoperiodism.

\section{Statistical analysis of biological parameters}

The data collected during field experiment was analyzed statistically to observe the effect of different factors or their interactions on the biological parameters like LAI, $K$ and RUE. Results revealed that, in each and every year, date of planting, variety and their interaction influenced the maximum LAI significantly (at $1 \%$ and $5 \%$ level of probability). Only the interaction effect between DOP and variety was not significant for the year 2012-13. Light extinction coefficient values were also significantly affected by all the factors. Statistical analysis of stagewise RUE data shows that only DOP has significant effect on RUE but variety and interaction effect do not show the significant result.

With the help of Angstrom equation, the GSR can be calculated on daily basis and $45 \%$ of GSR can be taken as incident PAR over crop surface. If the LAI is measured regularly and $K$ value of grown crop variety is known, the IPAR can be calculated using the method followed in this paper. Thus the whole process can properly be used to determine the IPAR and RUE, when the instrumental facilities (line quantum sensor and data logger) are not available (Fig. 5). In developing countries like India, such method can be popularized to generate RUE data, which may be used further for crop modelling and crop yield forecasting.

In conclusion, the Angstrom equation can be used reliably to determine the GSR in the study region. All the statistical indicators confirmed a close relationship between estimated and measured values of GSR. With the advancement of crop growth period, the intercepted portion of PAR increased up to a certain level, especially up to reproductive stages. Measurement of PAR interception pattern and LAI at different growth stages throughout growing season can provide average value of light extinction coefficient for a particular variety and transplanting-treatment. Thus it is possible to convert BSS data into GSR, GSR data to incident PAR and incident PAR

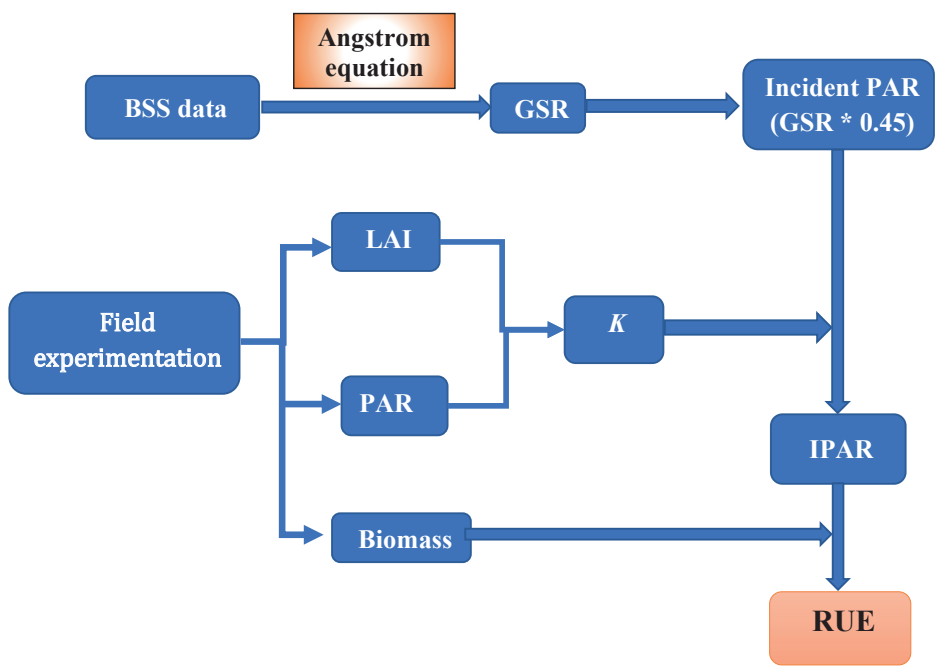

Figure 5. Suggested protocol for determination of radiation use efficiency (RUE). LAI: leaf area index. PAR: photosynthetically active radiation. IPAR: intercepted PAR. GSR: global solar radiation. $K$ : light extinction coefficient. RUE: radiation use efficiency 
to IPAR with the help of LAI and $K$ values. All of these above mentioned parameters are indispensable in the measurement of RUE which is found to be at the highest level during the last week of November in the study area. In respect to varietal preference, 'Kufri Chandramukhi' will be the preferred choice for the farmers as it possess the highest RUE throughout its growing period. It will enable scientists and researchers to calculate and monitor the radiation use efficiency without sophisticated radiation instruments or PAR sensors. In the developing countries like India, where the costly instruments are not easily available, such protocol may be used to determine PAR interception pattern and PAR utilization efficiency.

\section{Acknowledgement}

The help and encouragement of Director of Research, Bidhan Chandra Krishi Viswavidyalaya and Head, Dept. of Environmental Studies, Visva-Bharati, are duly acknowledged.

\section{References}

Akpabio LE, Etuk SE, 2003. Relationship between global solar radiation and sunshine duration for Onne, Nigeria. Turk J Phys 27: 161-167.

Allen EJ, Scott RK, 1980. An analysis of growth of potato crop. J Agric Sci, Camb, 94: 583-606. https://doi. org/10.1017/S0021859600028598

Angstrom A, 1924. Solar and terrestrial radiation. Quart J Roy Meteor Soc 50 (210): 121-125. https://doi. org/10.1002/qj.49705021008

Baigorria GA, Villegas EB, Trebejo I, Carlos JF, Quiroz R, 2004. Atmospheric transmissivity: distribution and empirical estimation around the Central Andes. Int J Climatol 24: 1121-1136. https://doi.org/10.1002/ joc. 1060

Bakirci K, 2009. Correlations for estimation of daily global solar radiation with hours of bright sunshine in Turkey. Energy 34: 485-501. https://doi.org/10.1016/j. energy.2009.02.005

Banerjee S, Das S, Mukherjee A, Mukherjee A, Saikia B, 2016. Adaptation strategies to combat climate change effect on rice and mustard in Eastern India. Mitig Adapt Strateg Glob Change 21: 249-261. https://doi. org/10.1007/s11027-014-9595-y

Battilani A, Mannini P, 1993. Effects of water table on potato crop growth and yield. Acta Hort Sci 335 (1): $405-$ 412. https://doi.org/10.17660/ActaHortic.1993.335.49

Beadle CL, 1993. Growth analysis. In: Photosynthesis and production in a changing environment: A field and laboratory manual; Hall DO et al (eds.). Chapman \&
Hall, London, pp. 36-46. https://doi.org/10.1007/97894-011-1566-7 3

Boken VK, Chandra S, 2012. Estimating leaf area index for an arid region using spectral data. Afr Crop Sci J 20 (4): 215-223.

Bowen WT, 2003. Water productivity and potato cultivation. In: Water productivity in agriculture: Limits and opportunities for improvement; Kijne JW, Barker R, Molden D (eds.). CAB Int, pp. 229-238. https://doi. org/10.1079/9780851996691.0229

Chiemeka IU, 2008. Estimation of solar radiation at Uturu, Nigeria. Int J Phys Sci 3: 126-130. https://doi. org/10.4314/ijonas.v3i2.36168

Coelho DT, Dale RF, 1980. An energy-crop growth variable and temperature function for predicting corn growth and development: Planting to silking. Agron J 72: 503-510. https://doi.org/10.2134/agronj1980.00 021962007200030023x

Condori B, Mamani P, Botello R, Patiño F, Devaux A, Ledent JF, 2008. Agrophysiological characterisation and parametrisation of Andean tubers: Potato (Solanum sp.), oca (Oxalis tuberosa), isaño (Tropaeolum tuberosum) and papalisa (Ullucus tuberosus). Eur J Agron 28: 526-540. https://doi.org/10.1016/j. eja.2007.12.002

Dammer KH, Wollny J, Giebel A, 2008. Estimation of the leaf area index in cereal crops for variable rate fungicide spraying. Eur J Agron 28 (3): 351-360. https://doi.org/10.1016/j.eja.2007.11.001

Demagante AL, Harris PM, Van der Zaag P, 1996. Variation among clonal lines of potato in response to irrigation regimes in an isohyperthermic environment. Field Crops Res 47: 191-200. https://doi.org/10.1016/03784290(96)00020-2

Demetriades-Shah TH, Fuchs M, Kanemasu ET, Flitcroft I, 1992. A note of caution concerning the relationship between cumulated intercepted solar radiation and crop growth. Agr For Meteorol 58 (3-4): 193-207. https://doi.org/10.1016/0168-1923(92)90061-8

Devaux A, Kromann P, Ortiz O, 2014. Potatoes for sustainable global food security. Potato Res 57: 185-199. https://doi.org/10.1007/s11540-014-9265-1

Dwelle RB, 1985. Photosynthesis and photoassimilate partitioning. In: Potato physiology; Li PH (ed.). Acad Press Inc., Orlando, FL, USA. pp. 35-58. https://doi. org/10.1016/B978-0-12-447660-8.50007-7

El-Sebalii AA, Trabea AA, 2005. Estimation of global solar radiation on horizontal surfaces over Egypt. Egypt J Solids 28: 163-175.

Fagbenle RL, Karayiannis TG, 1994. Evaluation of global and diffuse solar irradiation in Ibadan from specific humidity and relative sunshine. Int J Amb Energ 15 (2): 95-98. https://doi.org/10.1080/01430750.199 4.9675637 
FAO, 2014. FAOSTAT agriculture database. http://faostat.fao.org/DesktopDefault.aspx

FAO, 2017. FAOSTAT agricultural data. Agricultural production, crops, primary. http://faostat.fao.org/faostat/ collections?subset=agriculture

Favarin JL, Dourado Neto D, Y Garcia AG, Nova NAV, Favarin MDGGV, 2002. Equations for estimating the coffee leaf area index. Pesq Agropec Bras 37 (6): 769-773. https://doi.org/10.1590/S0100204X2002000600005

Finch DA, Bailey WG, McArthur LJB, 2004. Photosynthetically active radiation regimes in a southern African savanna environment. Agric For Meteorol 122 (3-4): 229-238. https://doi.org/10.1016/j.agrformet.2003.09.015

Gallagher JN, Biscoe PV, 1978. Radiation absorption, growth and yield of cereals. J Agr Sci 91: 47-60. https://doi.org/10.1017/S0021859600056616

Gardner FP, Pearce RB, Mitchell RI, 1985. Physiology of crop plant. Iowa State University Press, Ames, IA, USA.

Goudriaan J, Van Laar HH, 1994. Modelling potential crop growth processes, Kluwer Acad Publ, Dordrecht. https://doi.org/10.1007/978-94-011-0750-1

Haverkort AJ, Fasan T, Van de Waart M, 1991. The influence of cyst nematodes and drought on potato growth. 2. Effects on plant water relations under semi controlled conditions. Neth J Plant Pathol 97: 162170. https://doi.org/10.1007/BF01995965

Haverkort AJ, Verhagen A, 2008. Climate change and its repercussions for the potato supply chain. Potato Res 51 (34): 223-237. https://doi.org/10.1007/s11540-008-9107-0

Hijmans RJ, 2003. The effect of climate change on global potato production. Am J Potato Res 80: 271-280. https://doi.org/10.1007/BF02855363

Jacovides CP, Tmvios FS, Papaioannou G, 2004. Ratio of PAR to broadband solar radiation measured in Cyprus. Agric For Meteorol 121: 135-140. https://doi. org/10.1016/j.agrformet.2003.10.001

Jefferies RA, MacKerron DKL, 1989. Radiation interception and growth of irrigated and droughted potato ( $\mathrm{So}-$ lanum tuberosum L.). Field Crops Res 22: 101-112. https://doi.org/10.1016/0378-4290(89)90061-0

Khorasanizadeh H, Mohammadi K, 2013. Introducing the best model for predicting the monthly mean global solar radiation over six major cities of Iran. Energy 51: 257-266. https://doi.org/10.1016/j.energy.2012.11.007

Khurana SC, McLaren JS, 1982. The influence of leaf area, light interception and season on potato growth and yield. Potato Res 25: 329-342. https://doi. org/10.1007/BF02357290

Kiniry JR, Bean B, Xie Y, Chen P, 2004. Maize yield potential: critical processes and simulation modeling in a high-yielding environment. Agr Syst 82: 45-56. https://doi.org/10.1016/j.agsy.2003.11.006
Kiniry JR, McCauley G, Xie Y, Arnold JG, 2001. Rice parameters describing crop performance of four US cultivars. Agron J 93: 1354-1361. https://doi.org/10.2134/ agronj2001.1354

Kiniry JR, Wood CA, Spanel DA, Bockholt AJ, 1990. Seed weight response to decreased seed number in maize. Agron J 82 (1): 98-102. https://doi.org/10.2134/ agronj1990.00021962008200010023x

Levy D, Veilleux RE, 2007. Adaptation of potato to high temperatures and salinity-A review. Am J Potato Res 84: 487-506. https://doi.org/10.1007/BF02987885

Li H, Ma W, Lian Y, Wang X, Zhao L, 2011. Global solar radiation estimation with sunshine duration in Tibet China. Renew Energy 36 (11): 3141-3145. https://doi. org/10.1016/j.renene.2011.03.019

Li R, Zhao L, Ding YJ, 2010. Monthly ratios of PAR to global solar radiation measured at northern Tibetan Plateau, China. Sol Energy 84 (6): 964-973. https:// doi.org/10.1016/j.solener.2010.03.005

Loomis RS, Connor DJ, 2002. Crop ecology: Productivity and management in agricultural system. Cambridge Univ Press, UK.

Manrique LA, Kiniry JR, Hodges T, Axness DS, 1991. Dry matter production and radiation interception of potato. Crop Sci 31: 1044-1049. https://doi.org/10.2135/ cropsci1991.0011183X003100040040x

Martínez-Lozano JA, Tena F, Onrubia JE, Rubia JDL 1984. The historical evolution of the Angstrom formula and its modifications: review and bibliography. Agric For Meteorol 33 (2-3): 109-128. https://doi. org/10.1016/0168-1923(84)90064-9

McCree KJ, 1972. Test of current definitions on photosynthetically active radiation. Agr Meteorol 10: 443-453. https://doi.org/10.1016/0002-1571(72)90045-3

Meek DW, Hatfield JL, Howell TA, Idso SB, Reginato RJ, 1984. A generalized relationship between photosynthetically active radiation and solar radiation. Agron J 76: 939-945. https://doi.org/10.2134/agronj1984.0002 $1962007600060018 \mathrm{x}$

Menges HO, Ertekin C, Sonmete MH, 2006. Evaluation of global solar radiation models for Konya, Turkey. Energ Convers Manage 47: 3149-3173. https://doi.org/10.1016/j.enconman.2006.02.015

Minhas JS, Kumar D, Joseph TA, Raj BT, Khurana SMP, Pandey SK, Singh SV, Singh BP, Naik PS, 2006. Kufri Surya: a new heat-tolerant potato variety suitable for early planting in north-western plains, peninsular India and processing into French fries and chips. Potato J 33: 35-43.

Monteith JL, 1972. Solar radiation and productivity in tropical ecosystems. J Appl Ecol 9 (3): 747-766. https://doi.org/10.2307/2401901

Monteith JL, 1973. Principles of environmental physics. Edward Arnold, London. pp. 23-38. 
Monteith JL, 1977. Climate and the efficiency of crop production in Britain. Philos T Roy Soc London 281: 277-329. https://doi.org/10.1098/rstb.1977.0140

Moon P, 1940. Proposed standard solar-radiation curves for engineering use. J Franklin Inst 230: 583-618. https://doi.org/10.1016/S0016-0032(40)90364-7

Muzathik AM, Ibrahim MZ, Samo KB, Wan Nik WB, 2011. Estimation of global solar irradiation on horizontal and inclined surfaces based on the horizontal measurements. Energy 36:812-818. https://doi.org/10.1016/j. energy.2010.12.035

Myers DR, 2005. Solar radiation modeling and measurements for renewable energy applications: data and model quality. Energy 30: 1517-1531. https://doi.org/10.1016/j.energy.2004.04.034

NASA POWER, 2016. POWER Project, NASA's Applied Sciences Program, 2003. https://power.larc.nasa.gov/ data-access-viewer/

Nishibe SM, Satoh MM, Isoda A, Nakaseko K, 1989. Effect of climatic conditions on intercepted radiation and some growth parameters in potato. Jap J Crop Sci 58: 171-179. https://doi.org/10.1626/jcs.58.171

Page JK, 1961. The estimation of monthly mean values of daily total short wave radiation on vertical and inclined surfaces from sun shine records for latitudes 400N-400S. Proc Unit Nat Conf on New Sourc of Energ 98 (4): 378-390.

Pandey SK, Kang GS, 2003. Ecological zones and varietal improvement. In: The potato: production and utilization in sub tropics; Paul SM, Khurana, Minhas JS, Pandey SK (eds). Mehta Publ, New Delhi, pp. 48-60.

Praharaj CS, Govindakrishnan PM, Rawat S, Lal SS, 2007. Evaluation of the relationship between light use efficiency and solar radiation in potato. Potato $\mathrm{J}$ 34 (1-2): 129-130.

Prescott JA, 1940. Evaporation from a water surface in relation to solar radiation. Tran R Soc S Austr 64: 114-118.

Purcel C, Ball R, Reaper JD, Vories E, 2002. Radiation use efficiency and biomass production in soybean at different plant population densities. Crop Sci 42: 172177. https://doi.org/10.2135/cropsci2002.1720

Sabziparvar AA, Shetaee H, 2007. Estimation of global solar radiation in arid and semi-arid climates of East and West Iran. Energy 32: 649-655. https://doi.org/10.1016/j.energy.2006.05.005

Sahin AD, 2007. A new formulation for solar irradiation and sunshine duration estimation. Int J Energ Res 31 (2): 109-118. https://doi.org/10.1002/er.1229

Salima G, Chavula GMS, 2012. Determining Angstrom constants for estimating solar radiation in Malawi. Int J Geosci 3: 391-397. https://doi.org/10.4236/ijg.2012.32043

Samanta S, Banerjee S, Mukherjee A, 2012. Rainfall variability study over Kalyani Region (West Bengal). J Agrometeorol 14 (Special Issue): 401-406.
Sarmadnia GH, Koocheki A, 1994. Crop physiology. Publications Astan Quds Razavi, Ferdowsi University of Mashhad, p. 400.

Skeiker K, 2006. Correlation of global solar radiation with common geographical and meteorological parameters for Damascus Province, Syria. Energ Convers Manage 47 (4): 331-345. https://doi.org/10.1016/j.enconman.2005.04.012

Soltani A, Robertson MJ, Rahemi-Karizaki A, Poorreze J, Zarei H, 2006. Modeling biomass accumulation and partitioning in chickpea (cicerarietinum L). J Agr Crop Sci 192: 379-389. https://doi.org/10.1111/j.1439037X.2006.00220.x

Stuttle GW, Yorio NC, Wheeler RM, 1996. Interacting effects of photoperiod and photosynthetic photon flux on net carbon assimilation and starch accumulation in potato leaves. J Am Soc Hortic Sci 121: 264-268. https://doi.org/10.21273/JASHS.121.2.264

Tadros MTY, 2000. Uses of sunshine duration to estimate the global solar radiation over eight meteorological stations in Egypt. Renew Energ 21: 231-246. https:// doi.org/10.1016/S0960-1481(00)00009-4

Tavares Jr JE, Favarin JL, DouradoNeto D, Maia AHN, Fazuoli LC, Bernardes MS, 2002. Comparative analysis among methods of estimating coffee-tree leaf area. Bragantia 61 (2): 199-203. https://doi.org/10.1590/ S0006-87052002000200013

Temmerman LD, Wolf J, Colls J, Bindi M, Fangmeier A, Finnan J, Ojanpera K, Pleijel H, 2002. Effect of climatic conditions on tuber yield (Solanum tuberosum L.) in the European 'CHIP' experiments. Eur J Agron 17 (4): 243-255. https://doi.org/10.1016/S11610301(02)00064-3

Thornley JHM, France J, 2007. Mathematical models in agriculture: quantitative methods for the plant, animal and ecological sciences, $2^{\text {nd }}$ ed. CABI, Wallingford. https://doi.org/10.1079/9780851990101.0000

Trnka T, Zalud Z, Eitzenger J, Dubrovsky M, 2005. Global solar radiation in Central European lowlands estimated by various empirical formulae. Agr For Meteorol 31 (1-2): 54-76. https://doi.org/10.1016/j. agrformet.2005.05.002

Tsubo M, Walker S, 2005. Relationships between photosynthetically active radiation and clearness index at Bloemfontein, South Africa. Theor Appl Climatol 80 (1): 17-25. https://doi.org/10.1007/s00704-004-0080-5

Umoh MD, Udo SO, Udoakah YN, 2014. Estimating global solar radiation on horizontal surface from sunshine hours over Port Harcourt, Nigeria. J Electr Electron Eng Res 6 (1): 1-5.

Van der Zaag, DE, Doornbos JH, 1987. An attempt to explain differences in the yielding ability of potato cultivars based on differences in cumulative light interception, utilization efficiency of foliage and 
harvest index. Potato Res 30: 551-568. https://doi. org/10.1007/BF02367637

Vijaya Kumar P, Srivastava NN, Victor US, Ramana Rao $\mathrm{BV}, 1993$. Interception of photosynthetically active radiation (PAR) in castor (Ricinus communis L.) canopy in relation to leaf area development and cloud cover. Int J Ecol Environ Sci 19: 93-101.

Wang Q, Kakubari Y, Kubota M, Tenhunen J, 2007. Variation of PAR to global solar radiation ratio along altitude gradient in Naeba Mountain. Theor Appl Climatol 87: 239-253. https://doi.org/10.1007/s00704005-0220-6

Watson JD, 1947. Comparative physiological studies in the growth of field crops. I. Variation in net assimilation rate and leaf area between species and varieties and within and between years. Ann Bot 11 (1): 41-76. https://doi.org/10.1093/oxfordjournals.aob.a083148 Whisler FD, Acock B, Baker DN, Fye RE, Hodges HF, Lambert JR, Lemmon HE, McKinion JM, Reddy VR, 1986. Crop simulation models in agronomic systems. Adv Agron 40: 141-208. https://doi.org/10.1016/ S0065-2113(08)60282-5

Wright JL, Stark JC, 1990. Potato. In: Irrigation of agricultural crops-Agronomy; Stewart BA \& Neilson DR (eds). Monograph No. 30, ASA-CSSA-SSA, Madison, WI, USA.

Zarea MJ, Ghalavand A, Daneshian J, 2005. Effect of planting patterns of sunflower on yield and extinction coefficient. Agron for Sustain Dev 25:513-518. https:// doi.org/10.1051/agro:2005052 